PESHAWAR JOURNAL OF PSYCHOLOGY AND BEHAVIORAL SCIENCES, 2018, VOL. 4, NO. 2, 171-192

\title{
Role of Family, Neighborhood and Peers in Development of Delinquent Behavior in Adolescents
}

\author{
Shahana Masood ${ }^{1}$ and Saima Masoom Ali $^{2}$ \\ University of Karachi
}

\begin{abstract}
All over the globe juvenile delinquency is a major issue. Even after lots of efforts to minimize it, it is increasing. Therefore, the review paper aims on looking at the basic causes of development of delinquent behavior in adolescents. Objectives of this study are, finding out what role family plays in development of adolescents' delinquent behavior, what role neighborhood (local neighborhood or extra-local neighborhood) plays in development of delinquent behavior in adolescents, what role do peers play in development of delinquent behavior in adolescents and what role do economic factors and personal factors play in development of adolescents' delinquent behavior. Researches from past 12 years (from 2004 till 2016), including 39 papers, relevant to the study have been selected on basis of the keywords of the study from different websites PubMed, Wiley Online Library and some other online sociology, criminology and community psychology journal websites. Type of studies included in this paper are quantitative, qualitative, case study, cross-sectional and longitudinal studies. Results indicated family, peers, neighborhood, economic factors and personal factors are the reasons of development of delinquent behavior of adolescents. Interventions in keeping consideration of these issues should be planned for the reduction of juvenile crimes.
\end{abstract}

Keywords: adolescents, delinquent behavior, family, neighborhood, peers, economic status and personal factors

Juvenile delinquency is a global issue (Carter \& Stewin, 1999). It has been observed by United Nations Children's Fund (UNICEF) that more than 1 million world's children are in prison (Bochenek, M. G, 2016).

\footnotetext{
ISSN 2415-6779 EISSN 2518-4474

https://doi.org/10.32879/picp.2018.4.2.171

www.pjpbsicp.com
}

${ }^{1}$ M.Phil Scholar, Department of Psychology, University of Karachi

${ }^{2}$ Assistant Professor, Department of Psychology, University of Karachi 
Juvenile delinquent is defined as, "an adolescent who breaks the law or engages in behavior that is considered illegal" (John W. Santrock, 2011). Children who come under the age of 18 are considered to be juvenile and delinquent are the ones who show behavior which is illegal for adults. The term of delinquent will not be used for the child who is below age of 7 years and commits same kind of illegal act, this child would be called problem child due to the fact that at this age a child does not have the ability to differentiate maturely between right and wrong or legal and illegal act (Vijayanath et al., 2010).

According to FBI arrest statistics of juvenile offenders in US was $76 \%$ in $2008,78 \%$ in 2009 and $2010,77 \%$ in $2011,77 \%$ in $2012,78 \%$ in 2013 and 2014 (Puzzanchera, 2017). The rate of juvenile delinquency cases in US dropped from 52.3 per 1000 juveniles in 2005 to 28.1 in 2015 (Puzzanchera, S., 2018). Juvenile rates for all offences in US has been increased in the last two decades in year 1996 and later it is declined 70\% by year 2016 i.e. rate of crime in 1980 was 6,396 whereas it declined to 2,553.6 in 2016 (OJJDP, 2017). It shows that percentage of juvenile offenders is decreasing by almost 1 percent or less year by year from 2006 to 2012 (OJJDP,2017) but in further research as per the National Report 2014 , it was predicted that in $21^{\text {st }}$ century juveniles will increase. According to the estimation of Census Bureau 10\% increase of juveniles will be shown between 2010 and 2035. By year 2050, Juvenile population will be 16\% greater than in 2010 (MSaCP,2014).

US law enforcement agencies have arrested 1.6 million of juvenile offenders (most of them were involved in assault, larceny-theft, drug abuse violation and disorderly conduct offenses) in year 2010. Out of which 73\% are between age group of 16-17 years (MSaCP,2014).

According to Youthful Offender Industrial School (YOIS) Karachi statistics 85 per month juvenile offenders have been arrested and overall 3592 had been arrested in year 2011 Karachi only. These children were involved in various crimes such as, robbery, car lifting, pick pocketing, murder and sodomy (Hasni, 2011). Number of juvenile offenders in detention centers of Pakistan was 1,383 (1,246 are on trial and 137 have been convicted) out of which 783 were of Punjab, 276 of Sindh, 217 of Khyber Pakhtunkhwa and 107 of Baluchistan (Mansoor Hasan, 2014) 


\section{Theories on Development of Delinquent Behavior}

As per Hirshi's (1969), Social Bond Theory of Crime a person is likely to develop delinquent behavior when his link with society is weakened. As per Hirshi, concept of "social bond" consists of the four elements: (1) attachment, (2) commitment, (3) involvement, and (4) beliefs. Person who is strongly attached with his society will less likely deviate from the social norms. Commitment is being tangled in social activities and institutions, those who are committed to norms of their society will not become deviant. Involvement includes how much time you are spending in your community or neighborhood the more an individual is involved $\mathrm{s} / \mathrm{he}$ will not have time to move towards delinquent acts (in a case when community itself is not involved in deviant acts). An individual's belief on social norms and moral values also becomes hurdle for moving towards wrong path. Therefore, an individual is affected by the neighborhood they reside.

Social learning theory by Bandura indicates that an individual does observational learning which means that we try to model what others do by watching them doing. This theory can be applied in any context. This theory can also explain the phenomenon of learning through peers, which is an adolescent learns from their friends because $\mathrm{s} / \mathrm{he}$ spends most of her/his time with friends. Therefore, if a friend is involved in bad criminal acts there are chances of that child's involvement in criminal acts as well (McLeod, 2016) Another theory by a behaviorist B. F. Skinner (1953), within context of delinquent behavior explains that, children's behavior is shaped by reinforcement and punishment. A child's behavior is shaped by the environment s/he lives in, those behaviors are increased which are rewarded in the society or community or the family.

\section{Media and Juvenile Delinquency}

Media has negative impact on behavior. Watching violent content on media causes youth to develop aggressive tendencies and anti-social behavior (Anderson et al., 2002). Most of the time adolescents become victim of cyber-bullying on social networking sites. It can negatively affect mental health of youth who are being victimized (Slonje et al., 2013) and bullying is a predictor of delinquent behavior (Bender and Losel, 2011). 


\section{Rationale}

Global crime rate is increasing year by year especially juvenile crimes, which are hurdles for the growth of the society. A lot of researches are conducted almost each year in most of the regions of the world for finding out main reasons of juvenile delinquency despite of that it is increasing. More juvenile offenders were arrested as compared to adults as per the record of crime arrest in US by National Centre for Juvenile Justice 2014, which is the reason that more reaches are required in finding out the reasons of increased juvenile crime.

Purpose of conducting review on role of family, neighborhood, peers, economic factors and personal factors on adolescent's delinquent behavior is to understand what are the causes of these issues and which areas need improvement so that those areas can be worked upon.

Another reason is greater number of researches are required in this field so that adolescents can improve and those who are involved in crimes they can be stopped by trying to reduce the causes that are aiding in development of such delinquent behaviors. Work on adolescents is important because future of society relies on them.

As this study also includes researches carried out in Pakistan therefore it would be helpful to understand the ratio and reason of adolescents' crime causes and their solutions in Pakistan as well or it would also highlight the difference between Pakistan and other countries.

\section{Objectives}

1. To identify effect of family on development of delinquent behavior in adolescents.

2. To identify effect of neighborhood on development of delinquent behavior in adolescents.

3. To identify effect of peers on development of delinquent behavior in adolescents.

4. To identify effect of economic factors on development of delinquent behavior in adolescents.

5. To identify effect of personal factors on development of delinquent behavior in adolescents. 


\section{Review}

\section{Family and Delinquent Behavior of Adolescent}

Most of the researchers have found that one of the crucial cause of delinquency is complications in family which leads to behavioral problems in an adolescent. As findings of the study by Elite 2006, family environment plays major role in development of delinquent behavior in adolescents.

Adolescents who live in non-traditional family (with single-parent) are more prone towards developing delinquent behavior than those adolescents who live in traditional (two-parent) family (Demuth \& Brown, 2004). McCurley and Sydney 2004, informed that those adolescents (12-17 years old) who live with family which includes both biological parents had lesser chance of having behavioral issues than those who live with other type of families. Association between delinquent behavior of adolescents and non-traditional family has been studied with context of age, socioeconomic status, gender, race, family size and place of residence. Adolescents aged between 12-17 years were selected in the study. It has been found that association is influenced by family size and age. More vulnerable to juvenile delinquency were older adolescents and those who lived in larger families. (Kierkus \& Hewitt, 2009). It was stated in study of Mullens Angela D. 2004, that adolescents who lived with single parent were prone to development of delinquent behavior but those who were with fathers only were more involved in criminal acts. Elite 2006, also reported in a study that gender of a parent matters adolescents who live with father have greater chance of being delinquent.

It has been noted that children of divorced parents has some common genetic qualities that makes them vulnerable towards becoming delinquent (Guo, Roettger \& Shih, 2006) but Barnes, McGue \& Lacono (2009) argue that delinquent behavior of a child is not a genetic factor, it is because of going through the phase of divorce of parents. Therefore divorce of a parent has relationship with adolescent delinquent behavior. Delinquency rate is higher in children of divorced parents and it does not depend on the age when divorce happened (Prestin-Latham, 2013).

As trend of cohabitation is increasing in US children who live with single-parent (who cohabitates with non-biological parents) they are also at risk of developing delinquent behavior (Apel \& Kaukinen, 2008). Alisha Parks (2013), did a research which also supported these findings and in addition to that it has been observed that there is greater influence of parental 
monitoring, attachment and involvement on an adolescent's violent behavior than the type of family structure. Schroeder, Osgood \&Oghia (2010), found in their study that dissolution of families is not linked with greater offending but family formation by marriage or cohabitation is linked with greater offending in adolescents.

Attachment with parents and variation in family time effects on offending behavior of adolescents. Attachment and detachment with parents and peers has effect on delinquent behavior of adolescents (Wampler \& Downs, 2010).

Barnes-Walker \& Mason (2004), studied the effect of parental behavior on adolescent's behavior. Four characteristics were discussed psychological control, parental warm, behavior control and conflict between youth and parents. Relationship was found of all the previous factors along with structure of a family and income of family with criminal activities in adolescents.

Research on supportive family environment has been conducted as well which suggests that at times having a supportive parental protection serves as obstacle for development of delinquent behavior in a child even in worst conditions in family (Derzon, 2005).

A case study method was used with juvenile offenders of Adyala Jail, located in Rawalpindi, to know the potential causes of Juvenile crimes in Pakistan. Result indicated that main cause of delinquent acts of adolescents is facing neglect from family and poverty (Khursheed \&Urooj, 2012). Another study conducted in juvenile jail and borstal institutions located at Bahawalpur and Faisalabad in Punjab province specified that nagging attitude of father, parental conflicts, media and environment of community has greater impact on juvenile crimes (Mahmood \& Cheema, 2004).

Nisar et al. (2015), conducted study on male delinquents who were of age 16-18 were more involved in crime as compared to the younger one. Those who lived in joined family system had low chance of involving in juvenile crimes as compared to those who live in nuclear family system. The main cause of the juvenile crimes was found to be lack of education and low economic status. Negative personality is also affected by peer involvement as adolescents spend more times with their peers.

Javed et al. (2012), researched on juveniles at Faisalabad and Bahawalpur Borstal Jails of Punjab District. The results indicated that main causes of juvenile delinquency are a family's low income, conflict in a family, negative influence of peer, low education, revenge, and no parental supervision of a child.

PESHAWAR JOURNAL OF PSYCHOLOGY AND BEHAVIORAL SCIENCES, 2018, VOL. 4, NO. 2, 171-192 


\section{Neighborhood and Delinquent Behavior of Adolescent}

Adolescents are mostly found in neighborhoods next to their locality which are called extra-local neighborhoods. If an individual's extra-local neighborhood belongs to low socio-economic status it affects negatively on adolescents (Vogel \& South, 2016). If high-poverty locality adolescent is given examples of a better locality (means elders want them to be like them) around their neighborhood they develop delinquent behavior (Odgers et al., 2015).

It does not mean that the neighborhood in the residence has no impact on individual's behavior. It has been reported in a study that youngsters who are from disadvantaged neighborhood and have instable family are more likely to be involved in violent delinquent behaviors (Thornberry \& Hall, 2005).

\section{Peers and Delinquent Behavior of Adolescent}

Past researches explain the phenomenon of social learning theory, which is an individual learns from his/her peers. Bernasco et al. (2013), observed in research that adolescents who remains away from home with their peers (not near to a place where there parents can keep a check) are mostly involved in offending behaviors. According to Osgood \& Anderson (2004), unstructured socialization (socializing with people who do not follow rules of society) is found to be associated with delinquency.

Link with risk-taking peers is related to delinquency and aggression (Barnow, Lucht, \&Freyberger, 2005) across different countries (Beyers et al., 2004). Mostly adolescents who are involved in anti-social acts tends to be friend with those who are delinquent (Kiesner, Kerr \&Stattin, 2004). According to Paternoster et al. (2013), did experiment of delinquency exposure with adolescents and found out that $38 \%$ of adolescents showed signs of intention to do a delinquent behavior, it was the evidence of the effect of bad peers on adolescents' delinquent acts.

At times it also happens when an adolescent face rejection from peers they end up joining group which is involved in antisocial activities and support bad activities (Light \&Dishion, 2007) and then this behavior remains in adolescent till adulthood (Moffitt, 2006). Children who have lived in bad neighborhood and face conflicts of family make deviant friends in adulthood (Ingoldsby et al., 2006). The reason of involvement in deviant peers can also be ethnic or racial discrimination done with that adolescent (Gibbons et al., 2007). Adolescent chronic offenders do not blame their peer group for their

PESHAWAR JOURNAL OF PSYCHOLOGY AND BEHAVIORAL SCIENCES, 2018, VOL. 4, NO. 2, 171-192 
deviant acts but they are more involved in group offending (McGloin \&Stickle, 2011). It has also been noticed in a study that early puberty and deviant friends are the reasons of girls to be deviant (Murg et al., 2014).

\section{Economic Factors and Delinquent Behavior of Adolescent}

Previous researchers have found relationship between economic problems and delinquent behaviors. The research by Andrew et al. 2008, stated that those who had experienced economic complications reported greater amount of delinquency. It has also been reported that in year 2010, $22 \%$ juveniles who were imprisoned were from the family that lived below poverty level (National Centre for Juvenile Justice, 2014).

In US 39\% single-parents usually belongs to poor families, which can also be a main factor of juvenile crimes (U.S. Census Bureau, 2009). A longitudinal study done with adolescents noted that delinquency is high among those children who live in families and communities which are facing poverty, it was noted that there is greater influence of poor communities than poor families (Hay et al., 2007).

Wong (2011), found that poverty is the main factor that has effect on single-parenthood, divorce, and marriage later on these issues become cause of criminal acts in adolescents so in turn poverty indirectly has an effect on delinquent behavior. Chesney-Lind \& Shelden, 2014 described that to deal with socioeconomic disadvantage more girls are getting involved with gangs in Canada.

Nisar et al. (2015), found that low income is the one of the basic cause of juvenile crimes in adolescents. Javed et al. (2015), also defined low income of parents to be factor of juvenile delinquency. Study conducted in Borstal jail Faisalabad with age group of 16-18 juvenile offenders, it was observed that illiteracy and belonging to a low economic class supports the juvenile crime rate (Shamim et al., 2009).

\section{Personal Factors and Delinquent Behavior of Adolescent}

Surrounding factors has a significant role in development of violent delinquent acts but there is a role of personal factors as well such as personal level of education and experiencing a trauma in past. Failure in school is linked to development of delinquent behavior in children but this is the case more with girls than boys (Chesney-Lind \& Shelden, 2014). An adolescent who is less educated is more likely to get involved in criminal acts in adulthood (Meghir et al., 2012). 
Lansford et al. 2007, conducted a longitudinal study with children of age 5 till age 21 to note the development of criminal acts in those who had experienced physical abuse. It was observed that those who had exposure to physical abuse in first 5 years of their life had higher of being arrested for committing violent or non-violent crimes.

\section{Method}

Studies between 2004 till 2016, relevant to the topics of the study, have been included in this paper. Types of researches that has been part of data of the respective study are quantitative, qualitative, case study, crosssectional and longitudinal studies.

\section{Search Criteria}

Sample of the study has been selected from different search engines for the systematic review. Search engines are; PubMed, Wiley Online Library, Google Scholar and some other journals of sociology and criminology. Terms used to search for the data included Juvenile Delinquency, Delinquent Behavior, Criminal acts of a child, Juvenile offenders and Adolescent's Violent Behavior etc.

\section{Inclusion Criteria}

Only those researches were included in the study which were based on the objective of this study. Most of the research abstracts were reviewed as there was not complete excess of those articles few papers were fully reviewed and from those papers studies have also been included in the paper. All the studies included in the paper had were between years 2004 to 2016 only.

\section{Exclusion Criteria}

Those studies were excluded which were on delinquent behavior of adolescents but it was not based on criminal acts only it also included other delinquent acts. Studies before year 2004 were excluded as main aim was to include recent 12 years record.

\section{Procedure}

After collection of the review it was analyzed by the reviewers of the study per category of objective and results were obtained upon which discussion is based.

PESHAWAR JOURNAL OF PSYCHOLOGY AND BEHAVIORAL SCIENCES, 2018, VOL. 4, NO. 2, 171-192 


\section{Discussion}

The review paper aims at exploring basic causes of development of delinquent behavior in adolescents. Objectives of the study were; (1) to determine of family on development of delinquent behavior in adolescents, (2) to determine effect of neighborhood on development of delinquent behavior in adolescents, (3) to determine effect of peers on development of delinquent behavior in adolescents, (4) to determine effect of economic factors on development of delinquent behavior in adolescents and (5) to determine effect of personal factors on development of delinquent behavior in adolescents. Sample of the research is comprised of researches between years 2004 to 2016, relevant to the study topic.

All research questions of the review paper have been supported by the sample observed which means that there is a major role of family, neighborhood, peers, economic and personal factors in development of juvenile delinquent behavior among adolescents.

It has been observed that family environment plays crucial role in development of delinquent behavior. Findings suggest that family type, family size has greater effect on an adolescent's behavior. It has been identified who live in non-traditional families (single parent families) are at risk of developing delinquent behavior. Those who live in nuclear family were more prone towards developing delinquent behavior. Divorce of parents, parents living in cohabitation, family's neglect and low income negatively effects on an adolescent which can lead him towards path of delinquent acts.

Attachment and detachment with the parents also impacts on behavior of an adolescent. When a supportive family environment is provided to an adolescent it may act as an obstacle for developing delinquent behavior.

Adolescents who live in disadvantaged neighborhood and low socioeconomic locality are prone towards developing delinquent behavior. Exposure to extra local neighborhood also leads to delinquent behavior.

Delinquent behavior is the result of peer influence and socializing un-structurally. Spending time with peers who are risk takers and who are involved into anti-social activities can lead an adolescent to become delinquent. A child who faces discrimination from peers becomes delinquent. Belonging to low socio-economic family and community and economic complications in family are the cause of delinquent acts among adolescents. Low literacy rate, failure in school and facing abuse makes a child delinquent.

PESHAWAR JOURNAL OF PSYCHOLOGY AND BEHAVIORAL SCIENCES, 2018, VOL. 4, NO. 2, 171-192 
It has been predicted by the researches that there is a crucial role of family environment and structure in development of an adolescent's delinquent acts. Those who live in a non-traditional family i.e. single-parent family are likely to commit juvenile crimes. Rector Robert 2012, stated that there are issues in children of single-parent, they are at greater risk of being abused, facing academic problems and expressing weird behaviors which can lead them to be delinquent. Adolescents who live with fathers only are at high risk of involving in delinquent behavior, as a family is without mother and a child need mother for his healthy development it has been indicated in a study that even if a mother is separated for a week with a 3 years old or 5 years old child aggression and negativity is seen in those children (Howard, 2011) therefore in a study by Mack 2007, it has been specified that lack of maternal attachment can cause juvenile delinquency. Those who live in huge family are also likely to develop criminal act tendency. Having huge families can be problematic for a child as per their gender, in girls academic problems (poor reading skills and poor mathematics) arise whereas in boys behavioral difficulties are increased (Jaeger, 2016).

Divorce of a parent can also result in harm to a child in a way that $\mathrm{s} /$ he becomes criminal no matter how many years back the divorce of a parent took place. Sturt 2008, also described in study that delinquency can be caused by broken homes because an adolescent is negatively affected by divorce of parent and problem behavior is shown in a child of divorced family (Vander Valk et al 2005). After parent's divorce a child has to move into new situation as in economic situation of a family changes, parents give less time to a child and move to a new place which is the main cause of adverse effects on an adolescent as all of this is related to the personal wellbeing of a child (Nelson, 2009) one other reason of an adolescent's delinquent acts after parent's divorce is that parent-adolescent relationship is disturbed and a child sees conflicts in between parents after divorce, all these things prove to be lethal for an adolescent (Esmaeili \& Yaaacob, 2011).

Greater offending in adolescents also results from cohabitation of parents, which is more common in US, sometimes parents are living without marriage or at times a mother or a father lives with a non-biological parent of the child. More family disruption is shown in US and one of the factor of a disturbed family is cohabitation (which is an instable relationship itself) as well, it causes cognitive and behavioral problems in a child than the child of married couples (Ray, 2013) it does not fulfill a child's need in a proper manner, as relationship between wellbeing of a child and family structure is 
based on quality of parental relationship, resources given by parents, Mental health of a parent, involvement of father and level of parenting, if family is instable the child is affected negatively (Waldfogel, 2010).

An adolescent's attachment and detachment with parents is one of the major factors of delinquent behavior in adolescents than family structure, if there is strong attachment of parent and child there are lesser chances of a child to move towards delinquent criminal acts. Attachment in parents has relationship with delinquency in a child and to minimize juvenile delinquency attachment can be catered (Hoeve et al., 2012). Secure attachment with parent results in self-reliance, curiosity and independence in a child on the other hand insecure attachment with parents results in irritable, shy less confident child, they feel worthless and incompetent and are rejected by parents (Hong and Park, 2012). Children of parents who rejected and belonged to lower middle class showed aggressive behavior than children of middle class family (Bhatti \& Khoso, 2013). Behavior of a parent with child is also responsible for the development or nondevelopment of delinquent tendency in a child, those who have supportive parents will not be involved in juvenile delinquency. Supportive and warm maternal behavior showed development of brain that is growth of reward process in brain which is amygdala, development in area of emotions' reaction and regulation (Whittle et al., 2013).

Researches on role of family on delinquent behavior of adolescents of Pakistan stated that, Poverty in family, neglect from family, nagging father attitude, no parental supervision and parental conflict aids expansion of criminal behavior in a child. When a family goes through economic problems conflict started between parent and adolescent and depressive symptoms by mother warmth are shown (Delgado, Killoren \& Updegraff, 2013).Santrock 2012, described that neglectful parenting lowers self-esteem and make poor self-control of a child and will make a child delinquent. Joined family system is found to lower the chance of an adolescent getting involved in deviant acts. Destructive conflict between parents results in negative emotion (such as greater emotions reaction that are destructive and low level of emotional security) and behavior (such as inappropriate strategies of problem solving and greater aggressive behavior) (Barthassat, 2014).

Matalka and Hussainat 2012, conducted a study in Jordan which described that juvenile delinquency in adolescent is associated with family size, parental deprivation, economic deprivation, inter parental relationship, family discipline, parental acceptance-rejection and child-parent 
relationship, this research covers findings of most of the previous researches and it also suggested to conduct family counseling in order to minimize delinquent acts of adolescents.

After a family, role of neighborhood comes, that what role does a neighborhood has on enhancing or reducing juvenile delinquent acts of a child. Mostly there is greater impact of extra-local neighborhood than of the locality a child lives. Extra-local neighborhood is the neighborhood in near of the resident's neighborhood. If an adolescent spend time in an extra-local neighborhood where all are involved in bad acts s/he will likely be involved in such act too. As it is said that the area where person is found most of the time does same things as per norms of that region like when Pakistanis go to a foreign country and when they come back their way of talking living everything has changed. If a child live in poor neighborhood but along with that a better society is there so it can also impact negatively on the child because he is always given example for the good of the society. Whenever a child is given examples of others he feels envious towards others and end up being bad instead of good. A disadvantaged neighborhood also has an impact on delinquent acts. If a neighborhood is criminal and violent type it mostly affect males of the society and lead them towards delinquency (Damm \& Dustmann, 2012).Healthy Social and emotional development is seen among those youngsters who have positive bond with adults of community (Brennan, Barnett, and McGrath 2009).

Role of peers has also found to be significant in development of delinquent behavior. Socializing in unstructured way, staying away from homes for a longer times and spending time with bad peers are cause of delinquent behavior among adolescents. Those who have family conflicts and bad neighborhood they may be friends with delinquent individuals. Those who have exposure to criminal environment and meets with friends who provoke this behavior will likely develop juvenile delinquent behavior (Bayer, Hjalmarsson, and Pozen, 2009). According to Deming 2011, crimes can be reduced by being in better schools and with good peers. Peer pressure is the main reason of adolescent's variety behavior a as in a study it has been stated that risk taking behaviors as well because when an adolescent is with friends he does what is acceptable among the group because a reward system is activated which force them to act in a way, reduce in peer pressure/influence comes after teenage (Albert, Chein\& Steinberg, 2013). It also happens when a friend is kicked out of the group s/he joins antisocial group and one may join antisocial group in situations when $\mathrm{s} / \mathrm{he}$ is the victim of experiencing racial or ethnic discrimination. This happens because this 
makes child feel socially incompetent and the child becomes delinquent (Matalka, 2009).

Economic factor of an adolescent has an impact on delinquency of an adolescent. Facing economic hardships and belonging to low economic class are causes of an adolescent becoming delinquent. Living in poor families and neighborhood are also causing one to be deviant especially there is higher impact of poor neighborhood than poor families. There is a relationship between poverty and behavioral and academic issues in adolescents, poverty has an effect on development of an adolescent (Murry, 2011).

Some of the personal factor are also the cause of delinquency in an adolescent. Lack of education or low education and going through abuse as a child also results in one to become deviant. Failure in school has greater chances for girls to become delinquent. Low academic achievement is linked with weird behavior substance use, attention problem and delinquency (McLeod et al., 2012). Disordered psychological development and behavioral issues are shown in children who have faced child abuse (Odhayani, Watson and Watson, L., 2013).

\section{Conclusion}

Findings of the respective study suggests that family, peers, neighborhood, economic condition and personal history all of these factors contribute to some extent in shaping behavior of an adolescent, which can be delinquent when these factors affect negatively on a child in alternate condition these factors also helps in healthy mental growth of an individual. Such as having a supportive family environment would make a child a better person but if a child lives with non-supportive family or lives in broken families where parents are busy in dealing with their own issues and a child is neglected than he end up choosing a deviant path and he has greater chances of moving towards delinquency. In such scenarios kids goes to such neighborhood which are involved in criminal activities instead of being in their own areas and at this age being affected by peer influence is the basic reward for an adolescent therefore they do what friends do or at times they are left alone then they join group of criminals and become delinquent. Poor economic condition of a family or neighborhood both are the source of stress for the child and in turn child moves towards path of delinquency. At times there are no such factors that are discussed previously, instead of that there are some personal factors like someone is less educated and unemployed so 
he decides to join delinquent groups and at times an adolescent is abused as a kid after which behavioral issues are developed in child that can lead him towards delinquency. Therefore it has been suggested that a supportive and co-operating family and neighborhood can reduce the chances of children being involved in criminal activities. A secure-parent adolescent attachment, positive bond with adult of community, studying in better schools and being with good peers can prevent delinquent behavior of adolescents.

\section{Limitations and Recommendation}

Limitations of the respective review are that most of the studies on juvenile delinquency are conducted with males, females are targeted less. Cross cultural studies are not added in this review. Researches as per category of specific offence and its main cause are a few.

Recommendation for future work are that studies with girls should be conducted that can see causes of juvenile delinquency among them. More cross cultural comparison of research data is required so that common causes of juvenile crimes all over the world comes into consideration so that general interventions can be planned to target these causes. Researches as per category of offences should be added in the study so that more violent offences can be stopped before they put more children behind bars.

\section{References}

Agnew, R., Matthews, S.K., Bucher, J., Welcher, A.N., \& Keyes, C. (2008). Socioeconomic status, economic problems, and delinquency. Youth and Society, 40(2). doi:10.1177/0044118X08318119

Anderson, C. A., \& Bushman, B. J. (2002). Psychology: The effects of media violence on society. Science, 295, 2377-2379.

Apel, R. \&Kaukinen, C. (2008). On the relationship between family structure and antisocial behavior: Parental cohabitation and blended households. Criminology, 46, 35-70. doi: 10.1111/j.17459125.2008.00107.x

Albert, Chein\& Steinberg. (2013). Peer Influences on Adolescent Decision Making. Curr Dir Psychol Sci, 22(2): 114-120. doi: 10.1177/0963721412471347

McLeod, S. A. (2016, Feb 05). Bandura - social learning theory. Retrieved from https://www.simplypsychology.org/bandura.html 
Barnes-Walker, C., \& Mason, C. (2004). Delinquency and Substance Use among Gang-involved Youth: The Moderating Role of Parenting Practices, American Journal of Community Psychology, 34, 235250.

Barnow, S., Lucht, M., \& Freyberger, H. J. (2005). Correlates of Aggressive and Delinquent Conduct Problems in Adolescence. Aggressive Behavior, 31, 24-39.

Barthassat, J. (2014). Positive and Negative Effects of Parental Conflicts on Children's Condition and Behaviour. Journal of European Psychology, 5(1): 10-18. doi: http://doi.org/10.5334/jeps.bm

Bayer, Patrick., Hjalmarsson, Randi., \&Pozen, David. (2009). Building Criminal Capital behind Bars: Peer Effects in Juvenile Corrections. Quarterly Journal of Economics, 124 105-147.

Bender, D. \& Losel, F. (2011). Bullying at school as a predictor of delinquency, violence and other anti-social behaviour in adulthood. Criminal Behavior and Mental Health, 21(2): 99-106. doi: org/10.1002/cbm.799

Bernasco, Wim, Stijn Ruiter, Gerben J. N. B., Lieven, J. R., Pauwels, \& Frank, M. W. (2013). Situational Causes of Offending: A fixedeffects Analysis of Space-time Budget Data. Criminology, 51, 895926.

Beyers, J. M., Toumbourou, J. W., Catalano, R. F., Arthur, M. W., \& Hawkins, J. D. (2004). A Cross-national Comparison of Risk and Protective Factors for Adolescent Substance Use: The United States and Australia. Journal of Adolescent Health, 35: 3-16.

Bhatti \&Khoso. (2013). Difference in Parental Acceptance-Rejection and Personality Organization in Children of Hyderabad. Bahria Journal of Professional Psychology, 12 (2): 64-85.

Bochenek, M. G. (2016). Children Behind Bars. World Report 2016. Human Right Watch. Retrieved from: https://www.hrw.org/worldreport/2016/children-behind-bars

Brennan, M. A., Barnett, R. V., \& McGrath, B. (2009). The intersection of youth and community development in Ireland and Florida: Building stronger communities through youth civic engagement. Community Development, 40:331-345.

Burt, S.A., Barnes, A.R., McGue, M. \& Lacono, W.G. (2008). Parental divorce and adolescent delinquency: Ruling out the impact of common genes. Developmental Psychology, 44: 1668-1677.

PESHAWAR JOURNAL OF PSYCHOLOGY AND BEHAVIORAL SCIENCES, 2018, VOL. 4, NO. 2, 171-192 
Carter, S. P., \& Stewin, L. L. (1999). School Violence in the Canadian Content: An Overview and Model for Intervention. International Journal for the Advancement of Counseling, 21 (4): 267-277. doi: 10.1023/a:1005626408288

Chesney-Lind, Meda\& Randall G. Shelden. 2014. Girls, Delinquency, and Juvenile Justice. Toronto, Ontario, Canada: Wadsworth.

Damm \& Dustmann. (2012). Does Growing Up in a High Crime Neighborhood Affect Youth Criminal Behavior? Retrieved from: http://www.ucl.ac.uk/ uctpb21/Cpapers/Crime_2012_August_AE R.PDF

Delgado, Killoren \& Updegraff. (2013). Economic Hardship and MexicanOrigin Adolescents' Adjustment: Examining Adolescents' Perceptions of Hardship and Parent-Adolescent Relationship Quality. J Fam Psychol, 27(5): 827-837. doi: 10.1037/a0033737

Deming, David J. (2011). Better Schools, Less Crime? Quarterly Journal of Economics, 126: 2063-2115.

Demuth, S., \& Brown, S. L. (2004). Family Structure, Family Processes, and Adolescent Delinquency: The Significance of Parental Absence Versus Parental Gender. Journal of Research in Crime and Delinquency, 41(1): 58-81. doi:10.1177/0022427803256236

Derzon, J. H. (2005). Family Features and Problem, Aggressive, Criminal, or Violent Behavior: A Meta-analytic Inquiry. Unpublished manuscript. Calverton, MD: Pacific Institutes for Research and Evaluation.

Editor Cullen, F. T., Wright, J. P. \& Blevins, K. R. (Eds.). (2006). Taking stock: The status of criminological theory. New Brunswick, NJ: Transaction Publishers.

Editor MSaCP (Eds). (2014). Juvenile Offenders and VIctims: 2014 National Report.

Eitle, David (2006). Parental gender, single - parent families, and delinquency: Exploring the Moderating influence of race /ethnicity. Social Science Research, 35: 727-748. doi: 10.1016/j.ssresearch.2005.06.003

Esmaeili, N. S., \& Yaaacob, S. N. (2011). Post-Divorce Parental Conflict and Adolescents' Delinquency in Divorced Families. doi:10.5539/ach.v3n2p

Gibbons, F. X., Yeh, H.-C., Gerrard, M., Cleveland, M. J., Cutrona, C., Simons, R. L., \& Brody, G. H. (2007). Early Experience with Racial Discrimination and Conduct Disorder as Predictors of Subsequent 
Drug Use: A Critical Period Hypothesis. Drug and Alcohol Dependence, 88: 27-37.

Guo, G., Roettger, M. E., \& Shih, J. C. (2006). Contributions of the DAT1 and DRD2 genes to serious and violent delinquency among adolescents and young adults. Human Genetics, 121(1): 125-136. doi:10.1007/s00439-006-0244-8

Hasan, M. (2014, May 25). Report highlights plight of Pakistani children. $D A W N$. Retrieved from https://www.dawn.com

Hasni, A. (2011). Juvenile Delinquency. The News Tribe. Retreived from: https://www.thenewstribe.com

Hay, C., Fortson, E., Hollist, D., Altheimer, I., \& Schaible, L. (2007). Compounded risk: The Implications for Delinquency of Coming from a Poor Family that Lives in a Poor Community. Journal of Youth Adolescence, 36:593-605.

Hirshi, T. (2017). Causes of Delinquency. New York. Routledge

Hoeve, M., Stams, Van der Put, C. E., Dubas, J. S., Van der Laan, P. H. (2012). A Meta-analysis of Attachment to Parents and Delinquency. J Abnorm Child Psychol, 40(5): 771-785. Doi: 10.1007/s10802011-9608-1

Hong and Park. (2012). Impact of attachment, temperament and parenting on human development. Korean J Pediatr, 55(12): 449-454. Doi: 10.3345/kjp.2012.55.12.449

Howard, Kimberly., Martin, Anne., Berlin, L. J., Brooks-Gun, Jeanne. (2011). Early Mother-Child Separation, Parenting, and Child WellBeing in Early Head Start Families. Attach Hum Dev, 13(1): 5-26. Doi: 10.1080/14616734.2010.488119

Ingoldsby, E. M., Shaw, D. S., Winslow, E., Schonberg, M., Gilliom, M., \&Criss, M. M. (2006). Neighborhood Disadvantage, Parent-child Conflict, Neighborhood Peer

Relationships, and Early Antisocial Behavior Problem Trajectories. Journal of Abnormal Child Psychology, 34: 303-319.

Jaeger Kyle. (2016, January 11). Bad News for Big Families. Attn. Retrieved from: http://www.attn.com/stories/5008/effects-of-big-families

Javed, M., Azhar, Z., Anwar, H. N. \&Sohail, M. M. (2012). Socio-Economic Factors Affecting to Juvenile Delinquency: A Study Conducted at Borstal Jails of Punjab. Asian Journal of Empirical Research, 183197.

Khursheed, F. \& Urooj, T. (2012). Causes of juvenile delinquency among teenagers in Pakistani context. Elixir Criminal Law, 45: 7793-7796. 
Kierkus, C.A. \& Hewitt, J. D. (2009). The Contextual Nature of the Family Structure/ Delinquency Relationship. Journal of Criminal Justice, 37:123-132.

Kiesner, J., Kerr, M., \& Stattin, H. (2004). Very Important Persons in Adolescence: Going Beyond In-school, Single Friendships in the Study of Peer Homophily. Journal of Adolescence, 27, 545-560.

Lansford, J. E., Miller-Johnson, S., Berlin, L J., Dodge, K. A., Bates, J. E. \& Pettit, G. S. (2007). Early Physical Abuse and Later Violent Delinquency: A Prospective Longitudinal Study. Child Maltreat, 12(3): 233-245. Doi: 10.1177/1077559507301841

Light, J. M. \& Dishion, T. J. (2007). Early Adolescent Antisocial Behavior and Peer Rejection: A Dynamic Test of a Developmental Process. New Directions for Child and Adolescent Development, 118, 77-89.

Mack, Kristin Y. (2007). Reassessing the family-delinquency association: Do family type, family processes, and economic factors make a difference? Science Direct Journal of Criminal Justice, 35 (1).

Mahmood, K. \& Cheema, M. A. (2004). Empirical Analysis of Juvenile Crime in Punjab, Pakistan. Pakistan Journal of Life and Social Science, 2(2):136-138.

Matalka, F. I. (2009). Low family income and juvenile delinquency. Journal of Education, 140(1) May, 414-428.

Matalka \& Hussainat. (2012). Juvenile Delinquency and Family Environment in Jordan. Journal of Sociological Research, 3 (2). Doi: $10.5296 /$ jsr.v3i2.2750

McCurley, C. \& Snyder, H. (2004). Risk, Protection, and Family Structure. Pittsburgh, PA: National Center for Juvenile Justice.

McGloin, J. M. \& Stickle, W. P. (2011). Influence or Convenience? Disentangling Peer Influence and Co-offending for Chronic offenders. Journal of Research in Crime and Delinquency, 48(3) 419-447. DOI: $10.1177 / 0022427810393019$

McLeod, J. D., Uemura, R. \&Rohrman, S. (2012). Adolescent Mental Health, Behavior Problems, and Academic Achievement. $J$ Health SocBehav, 53(4): 482-497. Doi: 10.1177/0022146512462888

Meghir, C., Palme, M., and Schnabel, M. (2012). The effect of education policy on crime: An intergenerational perspective. National Bureau of Economic Research. doi: w18145.

Mrug, S., Elliott, M. N., Davies, S., Tortolero, S. R., Cuccaro, P. \& Schuster, M. A. (2014). Early Puberty, Negative Peer Influence, and Problem Behaviors in Adolescent Girls. Pediatrics, 133 (1). 
Mullens, Angela D. (2004). The Relationship Between Juvenile Delinquency and Family Unit Structure. Theses, Dissertations and Capstones, Paper 750.

National Centre for Juvenile Justice. (2014). Population Characteristics. Juvenile Offenders and Victims: 2014 National Report, 2.

Nelson Laura. (2009). A Review of Literature on the Impact of Parental Divorce on Relationships in Adolescents. Retrieved from: http://citeseerx.ist.psu.edu/viewdoc/download?doi=10.1.1.389.910 $2 \&$ rep $=$ rep $1 \&$ type $=$ pdf

Nisar, M., Ullah, S., Ali, M., \& Alam S. (2015). Juvenile Delinquency: The Influence of Family, Peer and Economic Factors on Juvenile Delinquents. Scientia Agriculturae, 9 (1): 37-48. DOI: 10.15192/PSCP.SA.2015.9.1.3748.

Odgers, Candice L., Sachiko, D., Avshalom, C., Christopher J. B., \& Terrie E. M. (2015). Living Alongside More Affluent Neighbors Predicts Greater Involvement in Antisocial Behavior Among Low-income Boys. Journal of Child Psychology and Psychiatry, 56, 1055-64.

Odhayani, A. A., Watson, W. J., Watson, L. (2013). Behavioural consequences of child abuse. Can Fam Physician, 59(8): 831-836.

Office of Juvenile Justice and Delinquency Prevention (OJJDP). (2017). OJJDP Statistical Breifing Book2017.

OJJDP. (n.d). Easy Access to FBI Arrest Statistics: 1994-2012. Retreived from: https://www.ojjdp.gov/ojstatbb/ezaucr/asp/ucr_display.asp

Osgood, D. Wayne, and Amy L. Anderson. (2004). Unstructured Socializing and Rates of Delinquency. Criminology, 42, 519-49.

Parks, B. A. (2013). The Effects of Family Structure on Juvenile Delinquency. Electronic Theses and Dissertations, 2279.

Paternoster, R, McGloin, J. M., Nguyen, H. \& Thomas, K. J. (2013). The Causal Impact of Exposure to Deviant Peers: An Experimental Investigation. Journal of Research in Crime and Delinquency, 50(4). doi: 10.1177/0022427812444274

Prestin-Latham, C. R. (2013). Juvenile delinquency: A Comparative Analysis between Divorced and Married Homes. Masters Theses, 1152.

Puzzanchera, C. (2017). W. Easy Access to FBI Arrest Statistics 1994-2014.

Puzzanchera, S. (2018). Juvenile Court Statistics 2015 Pitsburg, PA: National Center for Juvenile Justice2018.

Santrock, J. W. (2011). Life-Span Development (13 ${ }^{\text {th }}$ ed.). America, New York. McGraw-Hill. 
Slonje, Robert, Smith, Peter K., \& Frisen, Ann (2013). The nature of cyberbullying, and strategies for prevention. Computers in Human Behavior, 29, 26-32

Ray Barbara. (2013, March 19). Cohabitation's Effect on Kids. Psychology Today. Retrieved from: https://www.psychologytoday.com/blog/adulthood-whats-therush/201303/cohabitations-effect-kids

Rector Robert. (2012). Marriage: America's Greatest Weapon Against Child Poverty. Heritage Foundation Special Report,117. Retrieved from, http://www.heritage.org/research/reports/2010/09/marriageamerica-s-greatest-weapon-against-child-poverty.

Santrock, John W. (2012). A topical approach to lifespan development (6th Ed.). New York: McGraw-Hill.

Schroeder, R. D., Osgood, A. K. and Oghia, M. J. (2010), Family Transitions and Juvenile Delinquency. Sociological Inquiry, 80: 579-604. doi:10.1111/j.1475-682X.2010.00351.x

Shamim, A., Batool, Z., Zafar M. I. \& Hashmi, N. (2009). A Study of Juvenile Crimes in Borstal Jail, Faisalabad, Pakistan. The Journal of Animal \& Plant Sciences, 19(2), 2009, Pages: 101-103.

Skinner, B. F. (1953). Science and human behavior. New York: Macmillan.

Sturt Gary. (2008). Theories of Crime. Retrieved from: http:/homepage.ntlworld.com/gary.sturt/crime/theocrim.htm\#farri ngton

Thornberry \& Hall. (2005). The Joint Impact of Family and Community Structure on Violent Delinquency. Office of Juvenile Justice and Delinquency Prevention. Retrieved from: https://www.ncjrs.gov/pdffiles1/ojjdp/grants/215999.pdf

U.S. Census Bureau. (2009). Births to unmarried women by country: 1980 to 2008. Statistical Abstract of the United States. Retrieved from: http://www.census.gov/acs/www/data_documentation/2009_releas e/

Vander Valk, I., Spruijt, E., de Goede, M.; Maas, C. \& Meeus, W. (2005). Family Structure and Problem Behavior of Adolescents and Young Adults: A Growth-Curve Study. Journal of Youth and Adolescence, 34(6): 533-46.

Vijayanath, V., Anitha, M. R., Raju, G. M. \& Babladi, P. (2010). Juvenile Delinquency. Biomedical Research, 21 (3): 257-259. 
Vogel, M. \& South, S. J. (2016). Spatial Dimensions of the Effect of Neighborhood Disadvantage on Delinquency. Criminology, 54(3): 434-458. doi: 10.1111/1745-9125.12110.

Jane, W., Terry-Ann, C. \& Jeanne, B. (2010). Fragile Families and Child Wellbeing. Future Child, 20(2): 87-112.

Wampler, R., \& Downs, A. (2010). Parent and Peer Attachment in Minority Males at High Risk for Delinquency. Clinical Social Work Journal, 38: 107-119.

Wong, S. K. (2011). Reciprocal Effects of Family Disruption and Crime: a Panel Study of Canadian Municipalities. Western Criminology Review, 12: 43-46.

Whittle, S., Simmons, J. G., Dennison, M., Vijayakumar, N., Schwartz, O., Yap, M., Sheeber, L., Allen, N. B. (2013). Positive parenting predicts the development of adolescent brain structure: A longitudinal study. Developmental Cognitive Neuroscience, 8, 7-17. doi: http://doi.org/10.1016/j.den.2013.10.006 